\title{
Through the wasteland: chronic depression
}

\author{
The patient first manifested chronic depression in 1972 when she attempted suicide. She was \\ admitted to a county asylum, where the conditions and treatment she received coloured her \\ subsequent lifelong depression
}

\author{
Jackie Hopson patient ${ }^{1}$, Jeremy Holmes retired consultant psychiatrist ${ }^{2}$
}

${ }^{1}$ North Devon, UK; ${ }^{2}$ Visiting Professor of Psychotherapy, University of Exeter, UK

\author{
This is one of a series of occasional articles by patients about their \\ experiences that offer lessons to doctors. The BMJ welcomes \\ contributions to the series. Please contact Peter Lapsley \\ (plapsley@bmj.com) for guidance. \\ To share more people's experience of depression go to: www. \\ healthtalkonline.org/mental_health/Depression
}

There is now a wasteland where the county asylum I was first admitted to once stood. My feelings about the closure of these huge hospitals are ambivalent; for me they were places of fear, punishment and long incarceration. Contact with doctors was rare. I saw a doctor once in the first two months of my stay. He told me I was very ill and would remain in the hospital for a long time, and said little else. Treatment was electroconvulsive therapy twice a week for everyone on my ward. There was medication but no occupational therapy, and no leaving the ward except for electroconvulsive therapy. The hospital's response to escape attempts (I made two via windows accidentally left open) was the padded cell, followed by a locked ward and three doses of chlorpromazine a day, in addition to the usual drugs. Conditions in the county asylums in the early 1970s are too well known for me to add more details here. However, they were the only refuges available for many, including me at times.

This inpatient admission coloured my subsequent life-long depression. It seemed that I was to be punished for my illness and sedated if I made demands. Escape from illness meant escape from mental healthcare. My mother reinforced this by telling me (with no irony at all) that, some years earlier, I would have been hanged for my suicide attempt.

In the early 1970s I was an undergraduate and my college and the university medical officer were supportive. I was asked to leave college until "well" but returned because it was my only home. In order to continue studying I was asked to sign a form promising not to kill myself. I saw no problem in signing anything that allowed me to continue because it meant a more tolerable life. The university medical officer was reliable and caring, but he did not understand that my family home was a dangerous place to be. It was thanks to this doctor that I was referred to the Charles Hood Unit at Bethlem Royal Hospital. I spent about eight months in this excellent therapeutic community after (just) graduating. I eventually discharged myself because it seemed worth trying to live an ordinary life.

Years of severe depression and frequent overdoses followed. There were also times of normality. Drugs seemed a blunt tool and I spent much of my time in a fog. It is impossible for me to tell how much of this was because of the depression and how much was because of the drugs. Long-term sleep deprivation added to the confusion. Occasionally I was an inpatient in other county asylums. I had no contact with friends from my school days because I believed they had dropped me because of my illness. I recently found out that they knew nothing of it, so it must have been my inability to face them that cut me off.

When I was 34 I found I was pregnant. This was to be a significant problem for a depressive. My general practitioner told me to think about an abortion. When I returned (too late for an abortion) he told me to consider adoption since "babies need some joy in their lives." In some despair at getting any antenatal care for a baby I really wanted, I went to a Well Woman clinic. Here I was given advice about how to demand antenatal care at my local hospital. My mental illness was made clear to everyone involved in my care and the visiting midwife found it necessary to warn me that my baby would be taken away if I failed to look after her. I constantly felt under suspicion as a new parent and continue to feel significant anxiety about my fitness for motherhood. (Perhaps I should mention that my now 23 year old daughter appears to be a happy and normal young woman.)

Another positive result of keeping my baby was that in order to have access to antenatal care my general practitioner insisted I see the consultant psychiatrist at my local hospital. This was to provide me with 23 years of therapeutic care, which gradually transformed my life into a livable existence with diminishing 
periods of inpatient treatment; and I learnt some techniques for self-preservation. The introduction of fluoxetine was also helpful, this being the first drug that had any effect on my depression.

A career was out of the question and work was an ongoing problem. Anxiety about supporting myself was always present. I could not get life insurance when my second husband died and I was concerned about how my daughter and I would survive if I were to become ill again. I found it was necessary to lie in order to get a job. An employer could only sack me if my lie was discovered. I spent a couple of years teaching after I was approached by the school where my husband taught. I had to bargain to be kept on for the second year, as the headmaster insisted that I should give up my post if I became depressed. In accordance with this verbal agreement I resigned from my teaching post after being admitted to the psychiatric ward of the local hospital (a much less frightening place than my first county asylum). After I completed an MA I sought careers advice from my university, being totally open about my history of mental illness. I was advised to sell things from the boot of my car. Clearly honesty about depression was unproductive.

I am now in a position when normal life exceeds depressive periods. I view times of depression as episodes that I have to sit out, knowing that they will go away. One problem that comes with being "well" is the need to persuade new doctors to continue prescribing my medication. Living in the United States brought further anxiety about obtaining the medication I required. Now back in the $\mathrm{UK}$, the local consultant psychiatrist assures me that his letter will mean any new general practitioner will continue to prescribe fluoxetine and sleep medication. I am sure I will be challenged again, but there is his letter on file to refer to.

I have a very supportive and helpful general practitioner and I am constantly aware of improvements in my ability to be "normal." I know that I have shared the experiences of thousands of other mental patients, and that I have been extremely fortunate in my care at Bethlem and in receiving excellent long-term psychotherapy. However, I remain afraid that I will not be believed or trusted because I am, and always will be, a mental patient.

Competing interests: None declared.

Provenance and peer review: Not commissioned; not externally peer reviewed.

Accepted: 20 November 2010

Cite this as: $B M J 2011 ; 342: d 93$ 


\section{A doctor's perspective}

Our patients are our best teachers. Jackie has taught me a huge amount about depression: what it feels like, the impact on sufferers' and their family, and what does and doesn't help.

I have seen the toll taken by this ubiquitous disease, no less devastating in its impact than other chronic conditions. Jackie, an able and enthusiastic student, could barely finish her course at University, her employment prospects have been blighted, her social life restricted, and her capacity for pleasure and fulfilment curtailed.

At their worst psychiatric services reinforce sufferers' feelings of isolation and powerlessness. I say this not just to distance myself from old-style mental hospital regimes, but also about my own initial attempts at working with Jackie. My efforts to 'interpret' her depression in terms of childhood trauma (for which there was much evidence) and unexpressed anger reinforced Jackie's feelings of exclusion and her conviction that she was to blame for her illness. What she needed was validation, confirmation that the world does treat the mentally ill differently, and understanding that to be depressed is at best to live only partly.

It was when I moved into a more supportive therapy mode that Jackie began to trust me. I am sure there were times she hated me and what I stood for. I learnt to respect and acknowledge that hatred and its legitimacy, despite knowing that such strong feelings are coloured by a depressive world view. Painfully, Jackie has taught me how corrosive the 'division of suffering' between patient and doctor can be. By acknowledging our own vulnerability we can lessen the need to project our disturbances into our patients.

Staying the course with Jackie has shown us both how favourable life events can become the starting point for recovery from depression. The devotion of Jackie's husband and her daughter's flourishing have made an enormous difference as Jackie has gradually emerged from her depression. Over the years we have moved from weekly to fortnightly and then monthly sessions, to 6-monthly with occasional extra meetings if required. We are now more likely to encounter one another at the local train station than the consulting room.

A long term therapeutic relationship can provide a secure base where illness can be explored, accepted and sequestered This can enable the sufferer to live with near-normality in the outside world. I suspect that the current fragmented psychiatric services, for all they avoid the horrors of Jackie's early experiences, may militate against this. If so, the life of psychiatrists and their patients will be the poorer for it.

Jeremy Holmes 